\title{
A Descriptive and Syntactic Analysis of Àhàn Pronouns
}

\author{
Timothy Adeyemi Akanbi \\ Department of Linguistics and Nigerian Languages, Ekiti State University, Ado-Ekiti, Nigeria \\ Email: yemiakanbi@gmail.com
}

Received 2 October 2014; revised 17 November 2014; accepted 2 December 2014

Copyright (C 2014 by author and Scientific Research Publishing Inc.

This work is licensed under the Creative Commons Attribution International License (CC BY). http://creativecommons.org/licenses/by/4.0/

(c) (i) Open Access

\begin{abstract}
This paper examines pronouns in Àhàn, a language spoken in the Southwest Nigeria, specifically in Òmùò-Ėkìtì, Ekiti East Local Government Area. In this language, the tone born by a pronoun is conditioned by the environment where it occurs. In other words, a first person pronoun subject can be a high, mid or a low tone. We also observe that in this language, pronoun can change its morphological form when it occurs in a particular syntactic environment as against the other. We shall also show, in the paper that pronouns in Àhàn inflect for tense.
\end{abstract}

\section{Keywords}

Pronoun, Environment, Person, Tense

\section{Introduction}

Àhàn is a language spoken by about 2000 inhabitants in Omuo-Obadore Ekiti in Ekiti East Local Government Area of Ekiti State in the Southwest of Nigeria. Though, situated within the Ekiti dialect extraction of Yoruba speaking language area, Àhàn is a distinct language from Yorùbá. Linguists have still not been able to find the proper classification for the language. However, Àkànbí (2014) following Elugbe (2012) classifies it as a branch of Ahanoid under Defoid sub-group. Earlier, Williamson (1989: p. 201), Capo (1989: p. 281), and Crozier and Blench (1992: p. 13) put Àhàn under the Akokoid branch of Defoid family group . Bennet and Sterk (1977) also classified Àhàn as one of Akokoidlects. Elugbe (1989) grouped Àhàn under Edoid sub-family. We believe that as more works are done on the language, the proper classification will be arrived at.

Figure 1, culled from Àkànbí (2014: p. 6), shows the classification of Àhàn language.

All languages in the world appear to have pronouns. This is so because pronouns are words used instead of a noun. Pronouns come in different forms depending on the syntactic position they appear in the sentence. Apart from the appearance of pronouns in different forms, pronouns also inflect for number. This means that there is 


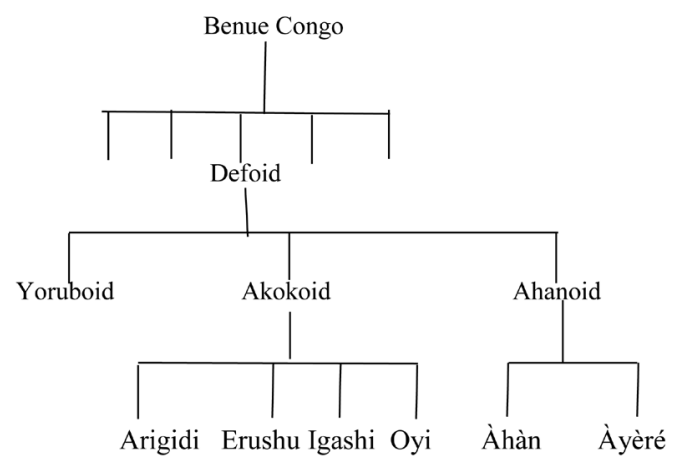

Figure 1. The classification of Àhàn (Culled from Akanbi, 2014: p. 6).

first person, second person and third person singular and plural pronoun subject and object. Scholars, at one time or the other have discussed pronouns in different languages of the world. In the literature, pronouns are grouped under functional category. The focus of this paper is to examine the pronouns of Àhàn. We are going to attempt both its descriptive and syntactic analysis. The paper is divided into three sections. Section one is the introduction. Section two looks at the pronouns of Àhàn. Section three will be the conclusion.

\section{The Pronouns of Àhàn}

Just like in other languages, the following pronoun types are attested in Àhàn.

1 i. Personal pronouns

ii. Anaphoric pronouns

iii. Relative pronouns

iv. Interrogative pronouns

In this present paper, our focus will be on the first two of these pronouns i.e. personal pronouns and anaphoric pronouns while the remaining two-Relative pronouns and Interrogative pronouns - will be the subject of other paper in some other time.

In the literature, scholars have given two different names to pronouns found in the languages of the world; short pronouns and long pronouns. However, in recent grammatical theories, these names have been changed to weak pronouns and strong pronouns. Today, short/weak pronouns and long/strong pronouns are also called antilogophor and logophor respectively; (See Ajíbóyè (2004), Adéșolá (2004, 2005), Manfredi (1987), and Sells (1987)).We shall look at the personal pronouns in 2.1.

\subsection{Personal Pronouns}

In line with the vast majority of pronominal paradigms in the world's languages, the traditional singular categories - speaker, addressee and other, are coded by three different morphemes in Àhàn. These three coded morphemes are known as first person, second person and third person respectively. The tables in (2a and $2 \mathrm{~b}$ ) below show the various forms of Àhàn pronouns both in the subject and object positions.

2 Àhàn Short/Weak Pronouns (Antilogophors)

(a) Subject ${ }^{1}$

\begin{tabular}{ccccc}
\hline Person & Singular & Gloss & Plural & Gloss \\
\hline $1^{\text {st }}$ & Ma & I & a & we \\
$2^{\text {nd }}$ & e & you & e & you \\
$3^{\text {rd }}$ & a (xà) & s/he/it & o & they \\
\hline
\end{tabular}

\footnotetext{
${ }^{1}$ We observe that the default tone of these pronouns in Àhàn is mid . However, the tone of the pronoun changes in conformity with the tone of the preceding verb or aspect markers. This is shown in our various examples.
} 
2(b) Object

\begin{tabular}{ccccc}
\hline Person & Singular & Gloss & Plural & Gloss \\
\hline $1^{\text {st }}$ & mi & I & à & us \\
$2^{\text {nd }}$ & rẹn & you & rẹn & you \\
$3^{\text {rd }}$ & $\varnothing$ & s/he/it & ywan & them \\
\hline
\end{tabular}

Pronouns in Àhàn do not inflect for features such as gender or animateness, which, from our observation, is a phenomenon common to virtually all Benue-Congo languages. However, pronouns in the language have morphological inflection. This makes the pronouns in Àhàn to be $n$ different forms for case endings and this is dependent on the syntactic position each of these pronouns occupies in a sentence. As will be shown from the various examples we shall present, the morphological form that these pronouns take either in the subject or object position is always different. We observe that the third person singular pronoun object in Àhàn is phonetically zero. In the following examples, the various pronouns identified in Àhàn which are listed in (2) above are used sententially.

(a)

3 1sg. subject Màyẹ rẹ ọkọ́lá 1 sg see 2 sg way I saw you on the way

4

2sgSubject
Égbújọ gbé
2sg must forget
You must forget
3sg Subject
àthèrù
3sg NEG/TNS eat
He did not eat

(b)

1pl. subject
àyẹ rẹ okọlá
1pl. see2sgway
We saw you on the way
2pl subject
Egbújọ gbé
2pl. must forget
You must forget
3pl subject
ọthèrù
3pl. NEG/TNS eat
They did not eat

The various pronouns in the subject position in Àhàn are used in (3 - 5) as seen from the examples above. First, second and third person pronouns are used in their singular and plural forms at the subject position. A close observation of (3b) and (5a) shows that the form of these pronouns is the same, even together with their tone $^{2}$. The difference between these two pronouns, i.e. 1pl subject and 3sg subject can only be interpreted in context. However, some speakers of Àhàn language pronounce the 3sg as $/ \mathrm{xa} /$. But this is limited to just few old people in the community. We assume that one of the forms must be the original. Probably synchronically, consonant $[x]$ of the pronoun got deleted and leaving only the vowel. Another reason may be due to the fact that articulatory organs normally want to go for the easiest pronunciation whenever there is alternative. We presume that this is what Awóbùlúyì (1967: p. 3) calls "economy of effort". And since it is easier for the articulatory organs to pronounce the vowel $[a]$ rather than the velar fricative $[x]$, it is easier to drop $[x]$. In the same vein, the 2 sg pronoun object and $2 \mathrm{pl}$ pronoun object also have the same form morphologically. This is evident in (46) below. The difference can only be realised through context.

We present, in the data below, the usages of these pronouns in the object position.

(a)

$6 \quad 1$ sg object

À lù mí

3 sg beat $1 \mathrm{sg}$ OBJ

He beat me

7 2sg. object

À lù rẹn (b)

1pl. object

à lù á

3 sg beat 1pl. OBJ

He beat us

2pl. object

À lù rẹn

${ }^{2}$ As we shall see later , tone plays a very significant role in the interpretation of pronouns in Àhàn . All these various pronouns can take different tones in different environment. Some pronouns inflect for tense, negation and emphasis through the tone they bear. This will be made clearer in the course of this work. 
3sg beat 2sg. OBJ

He beat you (sg.)

83 ss object

À lù

3sg. beat $\varnothing$

He beat him 3sg. beat $2 \mathrm{pl} \mathrm{OBJ}$

He beat you (pl.)

3pl. object

à lù ywan

3sg. beat 3pl. OBJ

He beat them

As we have noted earlier , the 3sg pronoun object in Àhàn is phonetically zero . This is shown in (8) above where the object is not phonetically realised. We assume that the reason for this dropping is to disambiguate third person singular pronoun in the object position from that of first person plural pronoun in the subject position (see 6b). Though, the verb used in (6) to (7) above is inherently low tone verbs, it can then be presumed that probably the dropping of the 3sg pronoun is peculiar to the environment of low tone verbs. But this is not the case. In (9) to (11) below, the verb with mid-tone is used, yet, the object still drops.

(a)

9

\section{1sg object}

A xe mí

3sg resemble 1sg OBJ

He resembles me

10 2sg. object

Axerẹn

3 sg resemble 2sg. OBJ

He resembles you (sg.)

11 3sg object

A xe

3sg. resemble ø

He resembles him (b)

1pl. object

axeá

3 sg resemble $1 \mathrm{pl}$. OBJ

He resembles us

\section{2pl. object}

Axerẹn

3sg. resemble 2pl OBJ

He resembles you (pl.)

\section{3pl. object}

axeywan

3sg. beat 3pl. OBJ

He resembles them

Still on this lack of phonetic content of 3sg at object position, we argue that the phenomenon has to do with language internal evidence. But before we return to further explanation on these examples, we shall give more data in order to make our general comments on them.

12 (a) Á fẹẹ̣Túndé

1pl. love Túndé

We love Tunde

(b) À thèrù a tujù

1pl. eat Prep. Farm

We ate at the farm

13 (a) Mí ké ruujù

1sg Perf.go farm

I have gone to the farm

(b) Mà ruujù

Isg.pst. go farm

I went to the farm

The data in $(12$ - 13) show the various occurrences of the personal pronouns in Àhan at the subject position. It will be observed that the same pronoun is realized in different forms, even in the same syntactic position. For instance, first person singular pronoun is realized as mí in (13a) and mà in (13b). There are two things to note. One, there is a change of tone and two, there is a change of form (see 13). But there is only a change of tone in (12); the form does not change. We posit that the change in form has to do with the type of tense of the following verb. What we have in (13a) is perfective aspect and that in (13b) is past/present tense. Therefore, we posit that pronouns in Àhan inflect for tense. Again, if we compare (12a) and (12b), even though, the segmental part of the first person plural pronoun does not change, there is a tone change. The change of tone on this pronoun is due to the type of verb that follows it. In (12a), we have stative verb fẹye "love" and in (12b) we have aktionsart verbthèrù "eat". Piernezi and Verze (2000: p. 15) say of aktionsart verb as representing 
...ways in which languages systematically divide eventualities into categories that are crucial to the meaning of verbs, verb phrases and sentences.

As we have observed in the data presented, the first person plural pronoun subject and the third person singular pronoun in the subject position have the same form. The form for these two pronouns is $[a]$ with a tone that conforms to the tone of the immediately following verb. The only way to disambiguate these pronouns is through context. However, as it has been shown, when the third person singular pronoun occurs in the object position, it normally does not have phonetic content. We give (14) and (15) as further examples of the similar forms of both the $1 \mathrm{pl}$ and the 3sg pronouns in the subject position.

14 (a) á á

1pl. come

We came

(b) á á

3pl. come

He came

15 (a) áká yún

1sg Perf.go

We have gone

(b) à à thèrù

3sg NEG. eat

He did not eat

The tone on the morpheme of the pronoun is not fixed. The tone on the morphemes of both the $1 \mathrm{pl}$ and the $3 s g$ pronouns varies. The variation depends on the contiguous item or the tense of the verb. For instance, (15b) takes a low tone instead of the mid tone which is the default tone on all the pronouns. The tone on the pronoun in (15b) is low because of the negative morpheme that has a low tone. Besides, this low tone marks the past tense on the verb. Further examples are given to buttress this point and to show that the following verb together with its tense dictates the tone of the preceding pronoun.
16 (a) Má yún
1sg go
I went
(b) Mé yún
1sg Asp go
I am going
(c) Mì yà yún
1sg hab. go
I used to go
(d) Miká yún
1sg. perf.go
I have gone

We have used the first person singular pronoun here as examples. What we see in (16) is a phenomenon that cuts across all the antilogophors in Àhàn language.

The table in (17) shows the long pronouns (logophors) in Àhàn.

\section{The long/strong pronouns in Àhàn (Logophors)}

\begin{tabular}{ccccc}
\hline Person & Singular & Gloss & Plural & Gloss \\
\hline $1^{\text {st }}$ & emi & I & aa & we \\
$2^{\text {nd }}$ & yghọ & you & ẹe & you \\
$3^{\text {rd }}$ & Un un & he & away & they \\
\hline
\end{tabular}

As shown in (17), all the logophoric pronouns in Àhànhave mid tone . Each of the pronouns in (17) is used in the sentences in (18 - 23) both at the subject and object positions. 
18 (a) Emi tìka kúù fẹ̀rẹ I also be there I am there also

(b) Òjó yẹ emi tika ufẹrẹ̣n Òjó see me also there Òjó also saw me there

19 (a) $A a$ tìka kúù fẹrẹ We also be there

We are there also

(b) Adé gbì aa nèyì yún

Adé take we two go

Adé took two of us/Ade went with two of us

(a) yghọ tìka kúù fệ̀

You (sg.) also be there

You are there also

(b) Tíșà kèé yẹrì yghọ tìka

Teacher want see you (sg.) also

The teacher wants to see you also

21 (a) Ẹẹ tìka kúù fẹrẹ̣ You (pl.) also be there

You are there also

(b) Olú yẹ ẹe ásí ùjù

Olú see you (pl.) Prep. farm

Olú saw you in the farm

22 (a) Un un tìka kúù fẹrẹ

$\mathrm{He}$ also be there

He is there also

(b) Olú sì un tìka á

Olú call him also come

Olú called him also

$\begin{array}{llll}23 & \text { (a) } \begin{array}{l}\text { Away tìna kúù } \\ \text { They also bèrẹ }\end{array} & \text { be } & \text { there } \\ \text { They are there also } & & \\ \text { (b) Mà mọ } & \text { away } & \text { tìka } \\ 1 \text { 1sg know them } & \text { also } \\ & \text { I know them also }\end{array}$

As can be seen from the data in (18 - 23), there is no noticeable difference between the forms of these logophoric pronouns both in the subject and object positions. Only that the third person logophor in the object position, as seen in (22b) has just un as opposed to un un in (22a). We propose that the reason for the change is as a result of the serial verb that we have in (22). In the absence of the serial verb, the 3sg logophor reverts to unun as seen in (23c) below.

23 (c) Olú lù un un tìka

Olú beat him also

Olu also beat him.

One other thing we observe on the issue of the third person pronoun in this language is the eratic nature of it. This may not be too surprising because even in English language, the third person pronoun behaves in a way different from all other pronouns in the language. This same phenomenon is observed in Yorùbá where the third person pronoun is not consistent in form like the other pronouns in the language. For instance, it is always phonetically zero in the environment before negation and future aspect in the Yorùbá language as shown in (24) and 
(25) below. The behaviour of this pronoun in the environment like this makes some scholars like Stahlke (1974), Awóbùlúyì (2001, 2006), Abíọdún (2007) and some others believe that Yorùbá does not have the third person singular pronoun.

24 (a) Ó

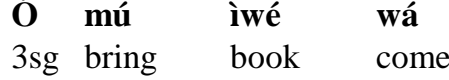

He brought the book

(b) ø kò mú ìwé wá

Null Neg bring book come

He did/does not bring the book

(a) ø yóò mú ìvé wá

Null Fut. bring book come

He will bring the book

\subsection{The Anaphoric Pronouns in Àhàn}

Anaphor is a kind of reflexivization which is a phenomenon that is present in all the languages of the word. Cornish (1986: p. 1) describes anaphor as

.... very simple and straightforward phenomenon, consisting of the avoidance of redundancy or repetition by the use of a semantically (and, optionally, lexically and phonologically) attenuated expression in place of the full, lexical expression initially used. By virtue of its pairing with the latter as "antecedent", the attenuated expression (the anaphor) repeats the reference, or the sense, which it has already established.

The simple interpretation one can give to the quotation above is that anaphora prevents repetition of the already mentioned item in one part of the structure in another part of the same structure.

In the literature, anaphor is divided into two types namely reflexives and reciprocals. We observe that reciprocals in Àhàn are not distinct from reflexives . Therefore, we shall limit ourselves to reflexive anaphor in this section.

The Yorùbá language has had a fair share of works done on anaphors in the language . Works that have been carried out on Yoruba anaphor include Manfredi (1987), Lawal (1997), İlọrí (1999), Adéșolá (2005), Ajíbóyè and Amoskaite (2005), Àkànbí (2010), etc. See also Chomsky (1981), Riemsdijk and Williams (1986), Haegeman (1991), Koopman (2004), for pronouns in English and other languages.

These two forms of anaphora, i.e. reflexives and reciprocals, have no clear cut distinction in many of the African languages (Zeller, 2011). This fact has earlier been noted by Ajíbóyè and Amorskaite (2005: p. 1) in the Yorùbá language that

...correspondence between form and meaning in the realm of reflexive and reciprocal construal is however not universally attested. In Yorùbá (like in the other languages of the Kwa family) we do not find a formal distinction between a reflexive and a reciprocal construal...Thus, in Yorùbá, one and the same phrase is associated with three different interpretations.

It is observed by many linguists that many of the Benue-Congo languages of Bantu extraction fall within the type of languages where there is virtually no way of differentiating reflexives from reciprocals. While some languages, like English, have both types distinctly clear, a language like Àhàn has no clear cut demarcation b etween the two types. The English examples in (26) are regarded as anaphors while those in (27) are reciprocals.

26 (a) I hurt myself

(b) John hurt himself

(c) Mary looked at herself in the mirror

(d) We know ourselves

(e) The boys did the work themselves

(f) You must do the work by yourself

27 (a) We love each other

(b) They helped one another to do the work

The italicised words in (26 a-f) are known as reflexives, while those italicised in (27a) and (27b) are recipro- 
cals. These two forms, in the literature, are called anaphors. As can be observed in the data, reflexive anaphors must have the same $\varphi$-Features (Phi-Features) with their antecedents. This is to say that they must agree in person, number and gender (for languages that manifest gender) with their antecedents. Apart from this, anaphors must be bound within their governing categories. Haegeman (1991: p. 192) puts this requirement in this form:

The reflexive and its antecedent must agree with respect to the nominal features of person, gender and number. Lack of agreement leads to ungrammaticality.

Going by the quotation above, the structures in (28) are ungrammatical in the English language.

28 (a) *I hurt himself

(b) *They hurt yourself

(c) *He hurt herself

(28a) is ungrammatical because of lack of agreement in person; (28b) is ungrammatical for lack of person and number correspondence while (28c) is ungrammatical because there is no gender agreement between the reflexive and its antecedent.

In Principles and Parameters Theory (PPT), the Binding Theory (BT) distinguishes pronouns from anaphors through what it called binding principles. In the BT, three principles, A, B and C are posited to be satisfied by each of the nominal elements. These principles are stated in (29).

$29[\mathrm{~A}]$ An anaphor is bound in its governing category

[B] A pronoun is free in its governing category

[C] An R-Expression is free everywhere

(Chomsky 1981: p. 188)

Haegeman (1991: p. 229) defines governing category thus:

The governing category for A is the minimal domain containing it, its governor and an accessible subject/ SUBJECT.

While she (Haegeman) explains accessible subject/SUBJECT in this way:

A is an accessible subject/SUBJECT for B if the co-indexation of A and B does not violate any grammatical principles.

In the various literatures, nominal elements are distinguished in terms of feature specifications in the ways specified in (30).
30 Anaphors
[+anaphor, -pronominal]
Pronouns
[-anaphor, +pronominal]
R-Expressions
[-Anaphor, -pronominal]

(cf. Chomsky (1981), Haegeman (1991), Carnie (2001), Kim and Sells (2007)), etc. We have gone this far in explaining the property of the anaphors so as to have a better understanding of our analysis of Àhàn reflexives . The next section discusses reflexive pronouns in Àhàn .

\subsection{Reflexive Pronouns and Other Reflexive Expressions in Àhàn}

Àhàn language manifests some reflexive expressions that can be used to indicate that a semantic or a syntactic argument of a predicate is co-referent with another argument of that predicate, typically, the subject. The following examples show the reflexive anaphors.

31 (a) Màiyẹ ọla-mi

1sg. seebody my

I saw/see myself

(b) Đghà ỵ̀ ọla-rẹn $n_{\mathbf{i}}$

2sg see body you

You saw/see yourself

(a) À̀ ỵ̀ ọla-rin

3sg seebody his 
He saw/see himself

32 (a) À Àyẹ ọla-a $\mathbf{a}_{\mathbf{i}}$

1pl. see body his

We saw/see ourselves

(b) : Èiyẹ ọla-ẹ́

2pl see body your

You saw/see yourselves

(c) ọ̀ yẹ ọla-ywan

3pl see body them

They saw/see themselves

\section{3 (a) Òjó gbà ọla-rinéńdí}

O. slap body his ear

Òjó slapped himself

(b) Bộlá yẹ̣ ọla-rin

B. see body her

Bộlá saw/see herself

Looking at the data presented in (31 - 33), one will observe that the reflexive pronoun in Àhàn comprises of a compound word made up of two morphemes ola- $x$. This phenomenon is not peculiar to Àhàn . Even, English language that is genetically unrelated to Àh àn uses a kind of compound word ( $x$-self) for its reflexives (see 26 above). In Yorùbá language, the reflexive anaphor is ara-x. Atóyèbí (2011: p. 3) notes this in Yorùbá and says that

Typologically, Yorùbá belongs to the group of languages in which the lexical source of the reflexive is contained in the expression of a body part, i.e., the word for "body" ara, which combines with a possessive pronoun. By reason of the fact that the reflexive occurs in a possessive frame, the final vowel of ara is always lengthened to reflect possession, hence, araax.

Therefore, the phenomenon of having words corresponding to self to form reflexives is pervasive in world languages. Van den Berg (2007: p. 35) reports that:

Creole reflexives derived from the noun for "body" or other noun denoting body parts are often associated with substrate influence in the literature, even though the claim for substrate influence as the source for the Creole body-part reflexives is not particularly strong.

Àhàn uses the same form to express both the reciprocal and reflexive. In other words, there is a kind of reflexive-reciprocal polysemy in the language. This is why there is a high degree of ambiguity in the reflexives in the language. Put in another way; reflexives and reciprocals in Àhàn are functionally similar and tend to behave syntactically alike. We presume that this may be the reason why both reciprocals and reflexives are treated on a par both being anaphors subject to the same binding principle "A" in BT of PPT. In (34) below, the italicised word can be interpreted both as reflexive and reciprocal.

34 (a) Bọ́lá àtì Șadéirànjè ola- $\boldsymbol{y w a n}_{i}$

Bọlá and Șadé meet body them

Bọlá and Șadé met each other/themselves

(b) Ò̀imọ àrẹnọla-ywan

3pl know workbody them

They know each other's work/the work of themselves

(c) À̀igè eó jì ola- $a_{i}$

1 pl give money for body we

We gave money to each other/ourselves

Hein and Miyashita (2008: p. 174) opine that languages derive their reflexives anaphors from a range of quite different forms ranging from pronouns, noun phrases and adverbial modifiers. Buttressing this point further, they present the table reproduced in (35) below to show how world languages normally derive their reflexives. 


\section{The main strategies to develop reflexive markers}

\begin{tabular}{ccc}
\hline & Label & Strategy \\
\hline a. & Pronoun & Use personal pronouns \\
b. & Intensifier & Add an intensifier (-self) to (a) \\
c. & Body & Use of a body-noun (+ possessive attribute \\
d. & Alone use & An adverbial "alone" or "only" \\
e. & Other sources & Mostly opaque \\
\hline
\end{tabular}

The following examples, (36 - 38) taken from Hein and Miyashita (2008: p. 174ff) presented each derivation of reflexives given in (35) above.

36 German (pronoun strategy)

Ichhabemichverletzt

I have me hurt

I've hurt myself

\section{Irish (intensifier strategy)}

Ghortaighseán é féin

Hurt Sean him self

Sean hurt himself.

\section{Yagaria-Papuan (Body strategy)}

d-ouva-dibegi-d-u-e

my-body-my beat-pst-1sg-ind.

I hit myself

Àhàn falls within the use of body-noun + possessive attribute.

On the reciprocal reflexive ambiguity, many other languages also do not make a clear cut demarcation. Heine and Miyashita (ibid.) cite examples of some world languages where there is no clear cut demarcation between the reciprocal and reflexive. Lango and Luo, two West Nilotic languages of Nilo-Saharan language family spoken in Kenya, use the same morpheme for both the reciprocal and reflexive. (39) and (40) below, taken from Hein and Miyashita (2008: p. 191) are examples.
39 wá-lwóko-rê
[Luo]

$1 \mathrm{pl}$ wash.Prf-Refl/Recp. $1 \mathrm{pl}$

(i) We have washed ourselves

(ii) We have washed each other

40 gínògóòy [Lango]

They 3.pl.beat.Mid.Prf.
(a) They beat themselves

(b) They beat each other

They (Heine and Miyashita) explain that the suffix rê in (39) is historically derived from a noun meaning body, and that this marker is used both for reciprocal and reflexive meaning.

As has been said, anaphors are handled in Binding sub-theory of GB syntax. Words like ola-mi "myself", ola-rin "himself”, ola-rẹn "yourself”, etc. are known as reflexives in Àhàn. Such items cannot be used to refer to some entity outside the structure within which they occur. They must be bound by some other entity in the same structure. Where this does not happen, such a sentence will be ungrammatical. We illustrate our explanation through the examples in (41).

41 (a) Mà yẹ ọla-mi

1 sg see body

I saw myself

(b) * Đghá

2 sg see body them 


\section{*You saw themselves}

The sentence in (41a) is grammatical because the $\varphi$-Features of both the anaphor and its antecedent agree. But (41b) is ungrammatical because the $\varphi$-Features of the antecedent and its reflexive do not agree. The antecedent $\eta g h a$ is a second person singular pronoun whereas that of the reflexive ola- $\eta w a n$ is third person plural.

One other issue in Binding Theory is the c-command. An anaphor must be c-commanded by its antecedent. This notion is stated in (42).

42 A bound constituent must be c-commanded by an appropriate antecedent.

We shall illustrate (41a) on a tree diagram in (43) to show how the rule in (42) is applied.

43

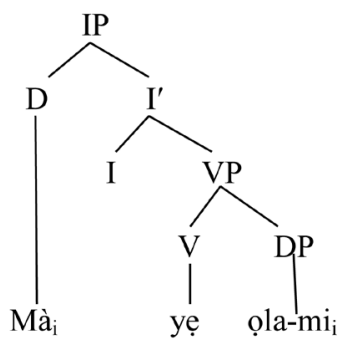

With a closer observation on the configuration in (43) in comparison with the rule in (42) it will be observed that the antecedent and anaphor no longer c-command each other and therefore the antecedent could not bind the anaphor; yet, the sentence is grammatical. What is the solution for this? The solution is to modify the notion of government and state it in terms of m-command as stated in (44a) and (44b) below rather than c-command.

44 (a) Government a governs $\beta$ iff

(i) $\alpha$ m-cammands $\beta$ and

(ii) $\beta$ m-commands a

(b) M-Command

a m-commands $\beta$ iff

(i) a does not dominate $\beta$;

(ii) $\beta$ does not dominate $a$

(iii) every maximal projection dominating a also dominates $\beta$ and

(iv) a does not equal $\beta$ (Hornstein et al. 2004: p. 79)

The configuration in (43) above conforms to the rule in (44b).

\section{Conclusion}

We have looked at the descriptive and syntactic analysis of Àhàn pronouns in this paper. We assert that pronouns in the language are conditioned by the tone of the verb immediately following it. We also adduce that pronouns in Àhàn also inflect for tense. Examples for these are given in the body of the paper. We have also shown in the paper that the syntactic and semantic behaviour of the third person singular pronoun in the language is unpredictable. This behaviour, as explained, is not peculiar to this pronoun in Àhàn alone, it is a phenomenon that cuts across many of the languages of the world. On the issue of reciprocals, we opine that there is no clear cut demarcation between reciprocals and reflexives in Àhàn. However, we observe that pronouns in Àhàn also conform to the rules of grammar within the Government and Binding of Chomsky's (1981) framework.

\section{References}

Abíọdún, M. A. (2007). ‘Ó’ kì í șeọrọ arọpò-orúkọ: Ệrí látí inú fonọlọijì. Paper presented at the Yorùbá Studies Association of Nigeria (YSAN) Conference.

Adéșọlá, O. (2004). Coda Deletion in the Yorùbá Phonology. In A. Akinbiyi, \& O. Adesọlá (Eds.). Proceedings of the 4th World Congress of African Linguistics. Cologne: Ruediger Koeppt Ventag. 
Adéșọlá, O. (2005). Pronouns and Operators-A Bar Dependencies and Relations in Yorùbá . Unpublished Ph.D. Dissertation. New Jersey: Rutgers, the State University of New Jersey.

Ajíbóyè, J. O. (2004). The Syntax of Yorùbá Genitive Construction. Paper read at the 35th Annual Conference of African Linguistics, Harvard, Boston.

Ajíbóyè, J. O., \& S. Amoskaite (2005). Yorùbá 3rd Person Pro-Form Are Pro-DPs. Proceeding of the 2005 conference of the Canadian Linguistics Society.

Àkànbí, T. A. (2010). Distribution and Interpretation of PRO in Yorùbá. Unpublished M.Phil. Dissertation, Ibadan: University of Ibadan.

Akanbi, T. A. (2014). A Descriptive Account of Àhàn Verb Phrase. An Unpublished Ph.D. Thesis, Department of Linguistics and Nigerian Language, Ado-Ekiti: Ekiti State University,

Atóyèbí, J. D. (2011). On the Syntax of Reflexives in Yorubá: A Descriptive Perspective. Paper Read at the Workshop on Universals and Typology of Reflexives, Universiteit Utrecht, Utrecht, 24-28 August 2011.

Awóbùlúyì, O. (1967). Vowel Harmony in Yorùbá. Journal of West African Languages, 1, 1-10.

Awóbùlúyì, O. (2001). Arópò-orúkọkúkúrú ẹnì kẹtaẹyọaṣolùwà. Yorùbá: Journal of the Yorùbá Studies Association, 2, 1- 8.

Awóbùlúyì, O. (2006). 'Ó’ kì í șearópò orúkọnínú èdè Yorùbá. Yorùbá: Journal of the Yorùbá Association, 3, 1-14.

Bennet, P. R., \& Sterk, J. P. (1977). South-Central Niger Congo: A Reclassification. Studies in African Linguistics, 8, 241-273.

Capo, H. B. C. (1989). Defoid. In J. T. Bendor-Samuel, \& R. L. Hartell (Eds.), The Niger-Congo Languages: A Classification and Description of Africa's Largest Language Family (pp. 275-290). Lanham, MD: University Press of America.

Carnie, A. (2001). Syntax. Oxford: Blackwell Publishers.

Chomsky, N. (1981). Lectures on Government and Binding: The Pisa Lectures. Dordrecht: Foris.

Cornish, F. (1986). Anaphora Relations in English and French: A Discourse Perspective. Beckenham: Croom Helm Ltd.

Crozier, D. H., \& Blench, R. M. (Eds.) (1992). An Index of Nigerian Languages. Dallas, TX: Summer Institute of Linguistics.

Elugbe, B. (1989). Some Tentative Historical Inferences from Comparative Edoid Studies. Kiabara, 2, 82-101.

Elugbe, B. (2012). Comparative Akekoid and West Benue-Congo. The International Congress Proto-Niger-Congo: Comparison and Reconstruction International Conference, Paris, 18-21 September 2012.

Haegeman, L. (1991). Introduction to Government and Binding Theory. New York: Blackwell.

Hein, B., \& Miyashita, H. (2008). Intersection between Reflexives and Reciprocals: A Grammaticalization Perspective. In E. König, \& V. Gast (Eds.), Reciprocals and Reflexives: Theoretical and Typological Exploration (pp. 169-224). New York: Mouton de Gruyter.

Hornstein, N., Nunes, J., \& Grohmann, K. K. (2004). Understanding Minimalism. Cambridge: Cambridge University Press. Ìlọirí, J. F. (1999). Ìtúpalẹ sintáàsì ìwẹyìnnínú èdè Yorùbá. M.A. Project, Ile-Ife: Ọbafẹmi Awolọwọ University.

Kim, J., \& Sells, P. (2007). English Syntax: An Introduction. Centre for the Study of Language and Information.

Koopman, H. (2004). The Syntax of Specifiers and Heads. London, New York: Routledge.

Lawal, N. (1997). Logophoric Pronouns in Yorùbá and the Movement to Infl versus Relativized Subject Hypothesis. The Long-Distance Reflexive Workshop, LSA Linguistics Institute, Cornell.

Manfredi, V. (1987). Antilogophoricity as Domain Extension in Igbo and Yoruba. Niger-Congo Syntax and Semantics, 1, 97-117.

Piernezi, J., \& Verze, W. (2000). Lexical Categories. Cambridge: OUP.

Riemsdijk, H. C., \& Williams, E. (1986). Introduction to the Theory of Grammar. Cambridge, MA: The MIT Press.

Sells, P. (1987). Aspects of Logophoricity. Linguistic Inquiry, 18, 445-481.

Stahlke, H. (1974). Pronouns and Islands in Yorùbá. Studies in African Linguistics, 5, 171-204.

Van den Berg, M. C. (2007). A Grammar of Early Stranan. Concept Manuscript Acadmisch Proefschrift. Goborente Hilversum, Germany.

Williamson, K. (1989). Benue-Congo Overview. In J. T. Bendor-Samuel, \& R. L. Hartell (Eds.), The Niger-Congo Languages: A Classification and Description of Africa's Largest Language Family (pp. 247-273). Lanham, MD: University Press of America.

Zeller, J. (2011). The Syntax of African Languages: A Review Ms. KwaZulu-Natal: University of Kwa-Zulu-Natal. 
Scientific Research Publishing (SCIRP) is one of the largest Open Access journal publishers. It is currently publishing more than 200 open access, online, peer-reviewed journals covering a wide range of academic disciplines. SCIRP serves the worldwide academic communities and contributes to the progress and application of science with its publication.

Other selected journals from SCIRP are listed as below. Submit your manuscript to us via either submit@scirp.org or Online Submission Portal.
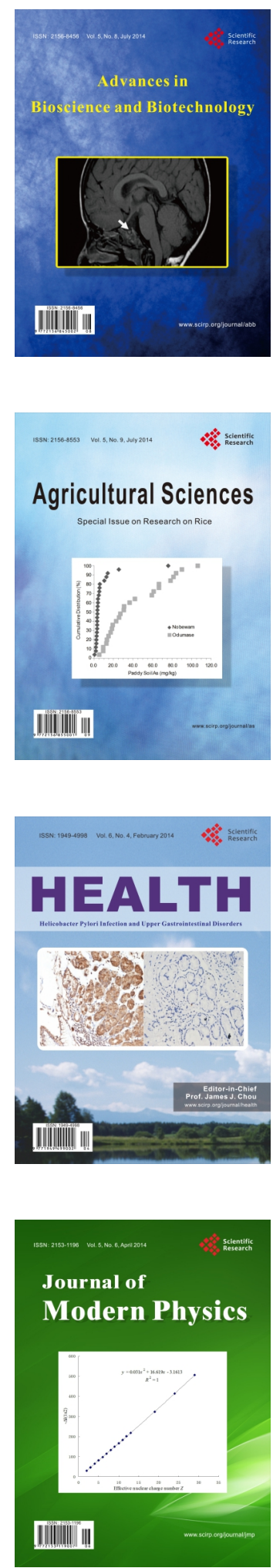
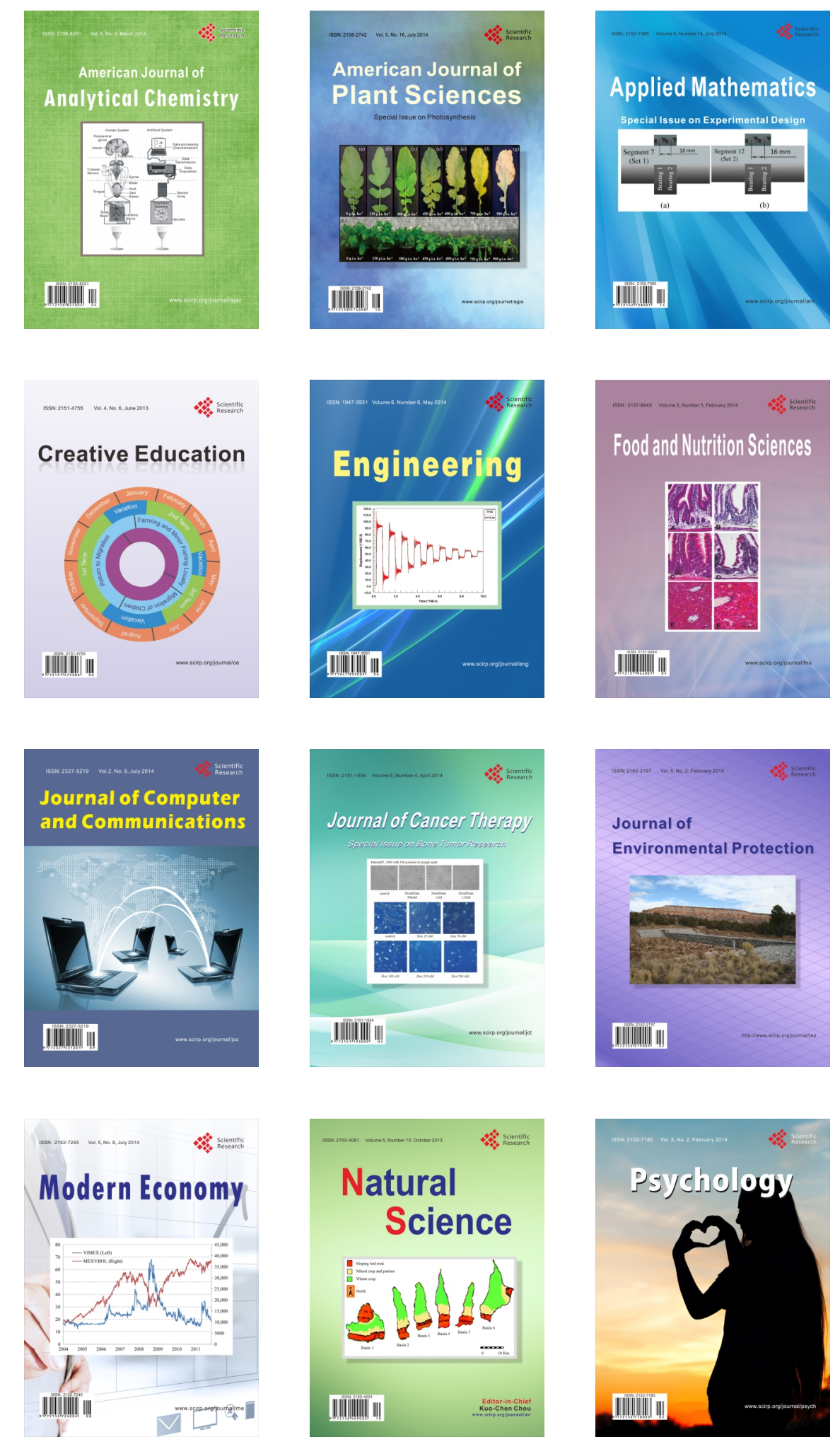